日臨外会誌 $59(5), 1179-1189,1998$

＜第59回総会特別パネルディスカッション>

「外科診療報酬の適正化にむけて」

司会 日本臨床外科医学会副会長 出月 康夫

” 日本臨床外科医学会副会長 日下部輝男

\title{
I，手術に対する診療報酬外保連試案について
}

外保連手術小委員会委員長 勝俣 慶三

はじめに

昭和 42 年当時の社会保険診療報㖄についてみると， 手術技術に対する手術科はあまりにも低く適正に評価 されていない，また同一診療科においても勿論のこと 各外科系診療科との間にも手術所定点数に著しい不均 衡があり全体として一貫性に欠けている.さらに手術 術式の呼称あるいは分類に不備不明な点が多く, 記載 されていない手術術式に対しては準用という形成を多 用するなどがみられ，各外科系学会において早くから 問題視検討していた経緯がある.

以上の状況を踏まえ, 当時の日本外科学会保健診療 委員長であられた島田信勝教授が日進月歩の医学, 医 術に即応した学術的根拠に基づき, 一貫性のある算定 方式により適正な手術報酬の評価法を確立する必要性 があると考え, 各外科系学会に呼びかけ賛意が得られ 外保連の誕生をみたのである。

以来，手術技術を学術的に適正に評価するには如何 なる根拠が必要かが討議され，まず基本的資料として 各学会における手術技術度区分（執刀者が自らの主体 的判断で手術を施行することができるという基準),手 術に伴う協力者数，人件費，手術料算定に係る間接経 費および付加的要素など検討し，これらに基づいて均 衡のとれた合理的な手術料を求めることを基本方針と し外保連試案第 1 版が作成された。

以後, 第 2 版 (昭和57年度), 第 3 版 (昭和62年度) と時代に相応した原資を基に改定が行われてきた。今 回の第 4 版作成に当たり当初の外保連の基本的理念を 邊守し, 理論と実際について大幅な見直しを行ったの で, その概要と現行の詞療報酬手術点数との相違につ いて述へたいと思う。

1. 手術料算定における基本的考え方および手術基 碟報非の構成要素（表 $1 ， 2$ ）
考え方, 構成要素については外保連発足当初からの 基本的理念と理論に則ることに変わりはない。すなわ ち手術料を積算するにあたり基本になる構成要素をあ らゆる面より検討した結果，理論的に算定が可能な基 礎報酬と理論的には算定が不可能な付加報酬に分けて 考えることが理論的で妥当であると合意が得られた。

さらに手術基礎報酬は，主として手街に関係する man powerの人件費からなる直接経費と手術を行 う設供に関連した間接経費に分けた。直接経費は執刀 者人件費（これは手術難易度にスライドする）と助手 などの協力者人件費（これは協力者数スライドする） に分けることが出来る.間接経費は設備を伴った手術 室の建設費とこれらの管理・運営費から構成し, これ らはいずれも手術難易度にスライドさせる。

2. 手術算定要素の再構成（表 3 ）

表 1 手術料算定における基本的考え方

算定体系：

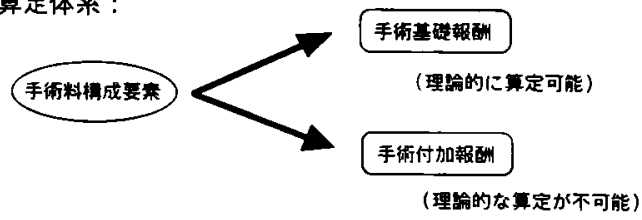

表 2 手術基礎報酬の構成要素

直接経費

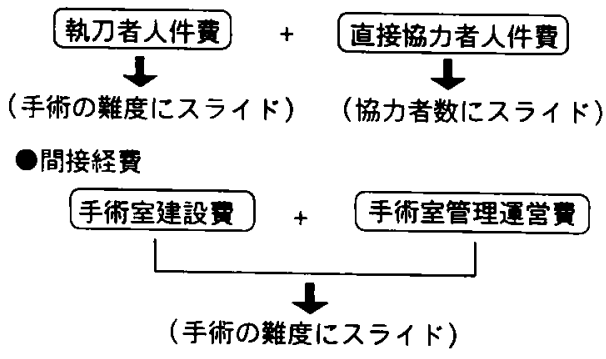


表 3 手術料算定要来の再構成

\begin{tabular}{|c|c|c|c|c|}
\hline & 手術料の内容 & 算定のための再構成 & & \\
\hline & I．人件費 & I，人件費 & & \\
\hline & （1）執刀者人件䩀算出額 & （1）執刀者人件費算出額 & & \\
\hline & (2) $\quad 11$ 調整費 & （4）協力者人件費算出額 & & \\
\hline & （3）執刀者技術料 & II. 間接経費 & & \\
\hline & （4）協力者人件費算出額 & （8）减価償却賀 & & \\
\hline & (5) II 調整費 & （9）医療機器等修理費 & 基礇報酬 & 各種資料を用いて計算 \\
\hline & （6）協力者技術料 & （10）建物維持管理費 & & \\
\hline & （7）勤務員人件賈 & （11）租税公課 & & \\
\hline 経費 & II. 間接経費 & （12）支払利息 & & \\
\hline & （8）減価供却費 & （13）消耗品絜, その他 & & \\
\hline & $\begin{array}{l}\text { (10) 建物維持管理珼 } \\
\text { (11) 租税公課 } \\
\text { (12) 支払利息 } \\
\text { (13) 消耗品費, その他 } \\
\text { (14) 引当金編入額 }\end{array}$ & $\begin{array}{l}\text { I. 人件費 } \\
\text { (2) 執刀者人件費調整费 } \\
\text { (3) 執刀者技術料 } \\
\text { (5) 協力者人件频調整费 } \\
\text { (6) 協力者技術料 }\end{array}$ & 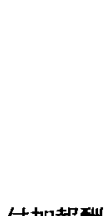 & \\
\hline 所得 & $\begin{array}{l}\text { III. 経常所得 } \\
\text { （15）法人税等充当額 }\end{array}$ & $\begin{array}{l}\text { II. 間接経費 } \\
\text { (14) 引当金綝入額 }\end{array}$ & 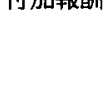 & $\begin{array}{l}\text { 産業界における椇益計算の } \\
\text { 利益率を参考にして基䃈報 } \\
\text { 酬に对する30\%加算とす }\end{array}$ \\
\hline & (16) 税引後所得 & $\begin{array}{l}\text { III. 経常所得 } \\
\text { (15) 法人税等充当額 } \\
\text { (16) 税引後所得 }\end{array}$ & & \\
\hline
\end{tabular}

手術報酬の構成と内容を検討すると, 手術費, 手術 室管理運営費, その他の費用および経営所得の総和が 手術報酬に相当するものと考える。これらの内容を項 目分類し，経費部分を人件費と間接経費とに編成替え する.さらにこの項目分類を手術報酬に適合するよう 再編成した．表 3 の左のカラムは手術に必要な費用の 内容を示す.右のカラムはその費用を算出するために, 基礎報酬の部分と付加報酬の部分に再構成したもので ある. 基礎報酬は各種の資料を用いて算出する. 付加 報酬は算出不可能な部分のため一括して産業界の損益 計算の利益率を勘案し, 基礎報酬に $30 \%$ 加算すること にした。

3. 手術技術度区分の設定について（表 4, 図 1)

手術技術度は手術の難易度により区分したもので, 普通群は執刀者が自らの主体的判断で手術を施行する ことができるという基準を基に，専門領域における経 験年数をもって示し順次的段階に難易度が上昇するこ とを鑑み, 第 1 群から第10群を設定し評価した。

それ以上は特群として第 1 群から第10群までの延長 上に仮設群を設定した。設定方法は普通群において単 位時間当りの報酬額を算出し, 第 10 群を 1.00 とし各分 群の対10群指数を求めグラフ化した.その曲線を反転, 再反転し第 4 象限に移し，11から20までの仮説群を設
表 4 手術技術度区分の設定（手術難易度の区分化）

○普通群

執刀者が自らの主体的判断で手術を施行することができ るという基準を、その再門領域における経験年数を持って 示したもの

第 1 群より第10群まで、順次に段階的に難度が上昇する

特群

第 1 群より第10群までの延長として, 仮設群を想定し，そ れを数群に分ける

定する．それをグラフ上の○印で示すように特群を 1 から 6 まで再区分し積算に用いた。

4. 基硞報酬算出の具体的仕組みについて(表 5,6) 第 3 版試案においては，国家公務員俸給表（昭和62 年度) を基に 1 等級 7 号体（医師初任給）を指数 1.00 としそれぞれの経験年数に対応するを算出している. しかしこの試算は経験年数による手術技術が反映され ていないため, 第 4 版試案では新たに医師経験年数給 与・技術度指数を導入し執刀者人件費を算出した。

医師給与係数は, 平成 6 年度国家公務員体給表医療 職第 1 号俸 (卒後 3 年目医師の俸給)これに家族手当, 退職金等など加え, 年間実働時間数で除すと時給は 6,400円となる.

医師経験年数給与・技術者度指数は，第 3 版試案で 
は俸給月額で, 経験年数の上昇に伴う級一号の俸給月 額を除して給与指数としており，医師の技術の上昇を 適正に表していないと考えたので, 手術小委員会で経 験的に能力が 3 年毎に 5 割増しが妥当であると結論に

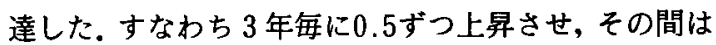
比例配分し技術度指数を設定し，技術度指数これに給 与指数を乗じ医師経験年数・技術度指数とし, 執刀者 人件費とした.

5. 直接手術協力人件費について（表 7, 図 2)

協力人件費は，協力者給与係数に協力者増加指数と

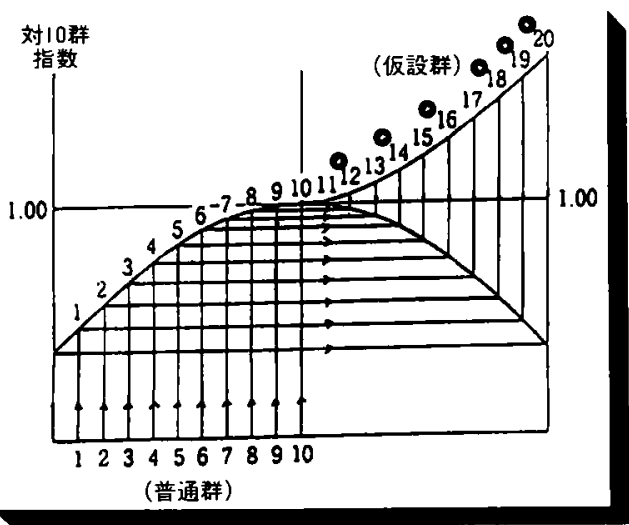

普通群において単位時間当たりの報酬額を算出し, 第10群を 1.00 とした場合の各区分群の対 10 群指数を求 めてグラフ化する

○その曲線を反転, 再反転して第 4 象限に移して, 11〜20までの仮説群を設定する。

仮説群を特群 1 〜 6再区分する。

図 1 特群の設定
所要時間を乗じ算出する.協力者給与係数は, 経験年 数 3 年の医師の時給 9,280 円と同じく経験年数 3 年の 看護婦の時給2,820円を加えたもので,第 3 版試案まで は手術の難易度が上昇すると上級の助手が参加するも のと計算されていたおり，実際の臨床の場では多くの 矛盾がみられている.第 4 版試案では平均として経験 年数 3 年目の医師と看護婦が手術助手となることとし た。しかし，手術技術の難度が增すに従い，当然協力 者 (医師, 看護婦) の増加が必要になってくる. 同時 に医師と看護婦の割合も変わることを考虑し，実際に 構成される協力者の指数を試算するに当たり, 医師, 看護婦各 1 名（協力者 2 ）の時点を1.00の指数（グラ フ上の四角点）としプロットした. 次に名点を通る近 似曲線を設定するとともに各協力者数との交点(O印) を協力者増加指数とし協力者人件費を積算した.

6. 手術間接経費について（表 8，9）

手術間接経費は, 間接経費指数に手術技術度区分間 接経費指数と手術室占有時間を乗して算出する. 間接

\section{表 5 算出の具体的仕組み}

・㛙刀者人件最の策出方式

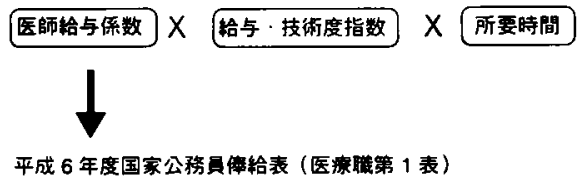

1 級 4 号俸 (卒後 3 年目)

6,400 円 / 時

表 6 給与・技術度指数

\begin{tabular}{c|c|c|c|c|c}
\hline 経験年数 & 級一号 & 俸給月額 & 給与指数 & 技術度指数 & 給与・技術度指数 \\
\hline 1 & $1-4$ & 2,505 & 1.00 & 1.00 & 1.00 \\
2 & $1-5$ & 2,612 & 1.04 & 1.17 & 1.22 \\
3 & $1-6$ & 2,728 & 1.09 & 1.33 & 1.45 \\
4 & $2-1$ & 2,880 & 1.15 & 1.50 & 1.73 \\
5 & $2-2$ & 2,998 & 1.20 & 1.67 & 2.00 \\
6 & $2-3$ & 3,117 & 1.24 & 1.83 & 2.27 \\
7 & $2-4$ & 3.237 & 1.29 & 2.00 & 2.58 \\
8 & $3-3$ & 3,501 & 1.40 & 2.17 & 3.04 \\
9 & $3-4$ & 3,625 & 1.45 & 2.33 & 3.38 \\
10 & $3-5$ & 3,747 & 1.50 & 2.50 & 3.75 \\
\hline
\end{tabular}

経験年数は各技術度区分に相当

級一号は国家公務員俸給表の卒後年次別俸給分類

給与指数は各俸給月額を $1-4(2,505$ 円) で除したもの

技術度指数は手術小委員会で設定

給与 $\cdot$ 技術度指数 $=$ 給与指数 $\times$ 技術度指数 
経費経費は上級手術室（第10群相当）を建設に要する 費用, 必要な医療機器および税金, 借入金利息, 管理 運営費等を膨大な各種資料より積算した。試算の結果 1 時間当たり 77,830 円となる.

なお，上記の手術度技術度区分間接経費指数は上級 手術室経費を 1.00 とし，外来手術室も同様に算定した 時間当りの経費を上級手術室経費で除した值を 1 群の 指数とし，1群より10群の間を配分し各技術度区分す る間接経費指数とした。

\section{表 7 算出の具体的仕組み}

○西接妱力者人件贯の算出方式

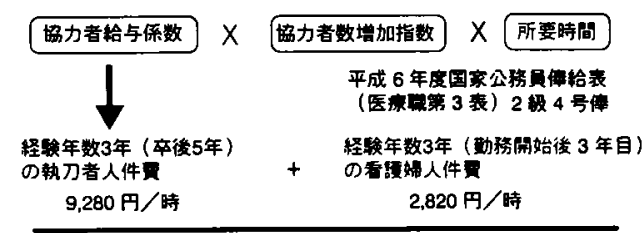

12,100 円 $/$ 時

表 8 算出の具体的仕組み

\section{-手術間接贯の箽出方式}

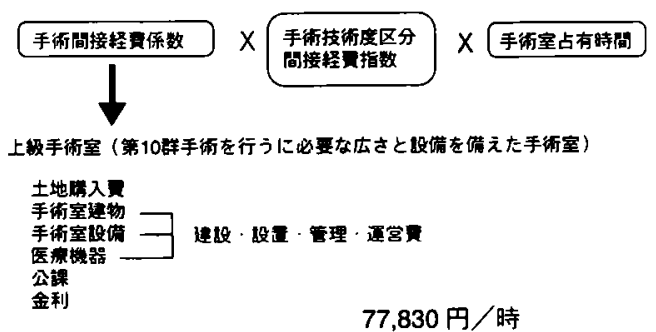

従い普通群の手術報酬額 (円/時) は執刀人件費, 協 力者人件費および間接経費のそれぞれの試算額を合計 し求め,さらに付加報酬として $30 \%$ 加算し, 単位時間 当りの手術報酬試算額を決めている（外保連試案第 4 版早見一臨表を参照)。

7. 試案第 4 版と現行診療報酬手術料の比較（表10）

一般的な手術として多く施行されている虫垂切除術 は, 試案によると技術度区分 5 , 術者を除いた協力者 数（医師 1 名, 看護婦 2 名）は 3 名, 手術時間は 1 時 間30分で197,300円となる。一方現行診療報酬手術料で は62,000円で対費用効果からみて大きな赤字である.

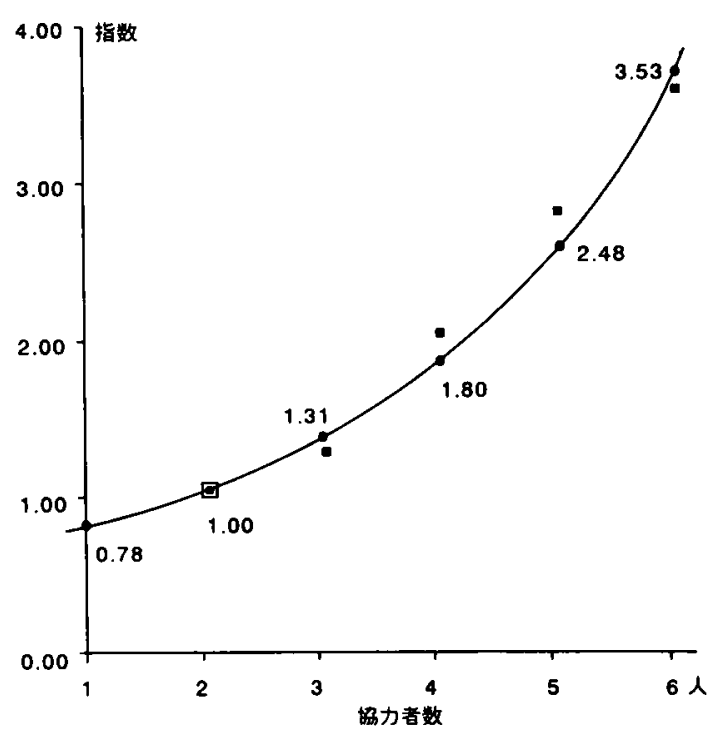

図 2 協力者数増加指数

表 9 算出の具体的仕組み

手術間接費の算出方式 手術技術度区分間接経費指数

\begin{tabular}{c|c|c}
\hline 技術度区分 & 間接経費指数 & 備考 \\
\hline 1群 & 0.27 & 下基点 \\
\hline 2 群 & 0.40 & \\
3 群 & 0.52 & \\
4 群 & 0.63 & \\
5 群 & 0.72 & 中間点 \\
6群 & 0.81 & \\
7 群 & 0.88 & \\
8 8群 & 0.94 & \\
9群 & 0.97 & \\
\hline 10群 & 1.00 & 上基点 \\
\hline
\end{tabular}

外来手術室経費

(第 1 群手術を行うに必要な広さと設備を備えた手術室) 20,630 円/時

上級手術室経費

(第10群手術を行うに必要な広さと設備を備えた手術室) 77,830 円/時 
表10 手術報酬外保連試案 (第 4 版) と現行手術料との比較

\begin{tabular}{|c|c|c|c|c|}
\hline コード番号 & 手術術式 & $\begin{array}{l}\text { 技術度群 } \\
\text { 劦著数 } \\
\text { 手術時間 }\end{array}$ & 試案(円) & 現行 (円) \\
\hline $31-32$ & 甲状腺部分切除術 (片葉) & $6-3-1.5$ & 219,060 & 48,000 \\
\hline $33-33$ & 乳線腫瘍摘出術 $(<5 \mathrm{~cm})$ & $4-3-1$ & 117.870 & 26,000 \\
\hline $33-37$ & 乳線悪性腫癌摘出術 (郭清 + ) & $10-5-4$ & 807,000 & 180,000 \\
\hline $37-55$ & 肺綎䑿術 (胸腔鏡) & $8-4-4$ & 709,040 & 114,000 \\
\hline $38-50$ & 食道悪性腫准切断術 (胸腹部操作) & $4-5-7$ & $2,059,050$ & 446,000 \\
\hline $39-73$ & 食道裂孔ヘルニア手術 & $8-4-3$ & 531,780 & 126.000 \\
\hline $44-30$ & 下肢静脈筝抜去切除術 & $5-4-3$ & 418,980 & 105,000 \\
\hline $46-77$ & 鼠径ヘルニア & $4-3-1$ & 117.870 & 49.000 \\
\hline $48-46$ & 胃悪性腫疸手術 (切除, 広汎) & $10-5-4$ & 807,000 & 300,000 \\
\hline $48-48$ & 胃悪性腫㾺手術 (全摘, 広汎) & $4-5-7$ & $2.059,050$ & 440,000 \\
\hline $49-32$ & 胆要摘出術 (腹腔鏡) & $8-4-3$ & 531,780 & 183.000 \\
\hline $49-33$ & 胆茟摘出術 (開腹) & $8-4-3$ & 531.780 & 110.000 \\
\hline $50-33$ & 肝部分切除術 & $7-4-4$ & 662,120 & 157,000 \\
\hline $51-35$ & 粨頭十二指晹切除術 & $5-5-7$ & $2,181,900$ & 467,000 \\
\hline $53-33$ & 虫垂切除術 (開腹) & $5-3-1.5$ & 197.930 & 69,000 \\
\hline $53-52$ & 人工肛門造設術 & $4-3-1.5$ & 176,810 & 62,000 \\
\hline $54-38$ & 直腸悪性腫疱手術(底位) & $3-5-5$ & $1.311,400$ & 340,000 \\
\hline $54-39$ & 直腸悪性腫疸手術 (切除, 広汎) & $3-5-6$ & $1,573,680$ & 340,000 \\
\hline $55-03$ & 痔核根治手術 & $3-3-1.5$ & 151.820 & 50,000 \\
\hline $55-21$ & 痔瘦根治手術 (簡単) & $3-3-1$ & 101,210 & 32,500 \\
\hline \multicolumn{3}{|r|}{ 平均 } & 763.356 & 182,225 \\
\hline
\end{tabular}

また，胃癌手術で広汎切除，リンパ節郭清を伴う場 合, 試案では807,000円であるが, 現行診療報酬手術料 は300，000円と虫垂切除術と同様大きな開きがある.

次に臨床外科医が施行している手術を20項目抽出し 比較検討した．個々の手術をみると2.4倍から4.8倍と 開きがあるが，手術の難易度からみてほほ妥当なもの と考えられた。これらの合計平均額からみると試案で は763,356円, 現行手術料は182,225円と約4.2倍の違い を示している.

\section{むすび}

以上, 各保連試案第 4 版の概略および現行診療報酬 手術料との比較について述へたが外科は最近「仙しい, きつい, 儲からない」,さらに手術手技が適正に評価さ れていない等言われており, 若い人材が入局を避ける 傾向にある. 少なくとも外科医のやる気を起こさせ, 経済的にも評価されるような診療報酬の改定を望んで やまない.

\section{II．処置に対する診療報酬外保連試案について}

\section{外保連処置小委員会委員長 中村 純次}

9 外科系学会による第 1 回外科系学会社会保険委員 会連合 (外保連) が開催されたのは1967(S42) 年 7 月 26日であります.その 6 年後の 1 月に手術, 処置, 特 殊検查に関する各小委員会の活動内容が「社会保険診 療報酬に関する外保連における討議内容についての中 間報告」としてまとめられています。この報告書は手
術については可なりの形をなしていますが，処置に関 しては項目の羅列に過ぎません．しかし，翌年 3 月 13 日付の「処置に関する外保連の中間報告」がさらに残 され，これは(1)処置の概念, (2)難易度の判定, (3)難易 度別一筧表の 3 部からなり，この一覧表は 6 行為別に 区分され，165項目の処置行為が記載されております。 
内容的にも体系化され，具体性の高まったものとなっ ていますが, その後の進展, 報告はなく，この時点で 処置についての作業は中断してしまったようでありま す.

再出発にあたり，われわれは全委員の合意のもと基 本的にはこれらの資料内容を踏警することとしまし た。すなわち, 1994 (H6) 年10月 5 日, 13学会13名(現 在は21学会26名）の委員で構成された第 1 回処置小委 員会を開催し，本年10月末で21回を数え，この6月に は「処置報酬に関する外保連試案一第 1 版」の中間報 告を作成致しました。

本中間報告には15段階の技術度群に分けられた 490 項目に及ぶ外科系処置項目が, 30項目の行為別, また 手衍試案に準拠して68群の藏器別に分類され, さらに 各処置項目には処置料算定の基整的要素である技術度 区分, 直接協力者数及び所要時間が数字で与えられて おります。

当初各科から提案された処置項目の総数はおおよそ 600項目以上でありましたが, 同一処置でも技術度が異 なって重複しているものが多いため, まず技術度の整 合性を得ながら整理し，さらに協力者数，所要時間等 の数字の違いを統一しました。しかし検討を重ねるに 従い処置内容の複雑さから次々に疑問点が続出し, 場 合によっては $2 つ$ 処置に分解する, また長時間に及 ぶ処置に対しては管理時間因子を加算するなどの配慮 も必要でありました。このようにして全処置項目にわ たる審議を都合 4 回繰り返し,その後さらに物理療法, 自己血輸血の審議があり, 計 5 回にわたる検討を行い, その結果が 490 にふ処置項目となりました。これらは 各科の合意のもと確害な整合性をもって整理されたも のであります。「第 4 次整理案」が完成した 6 月の時点 で，先に述べたように「中間報告」を作成しておりま すが, 来年 4 月には第 5 次最終整理案を基に基礎的 3 要素から算出される具体的処置報酬を記載した初版を 出版する予定であります。

さて,われわれの処置料の算出の具体的方法は原則 的には手術試案（外保連方式）に準拠しております。 診療報酬としての処置料は基礎報酬と付加報酬から構 成されます。まず基礎報酬とは原価計算的に積算根拠 を明らかにできるもので，処置術者人件費と協力者人 件費及び処置間接経費から構成されています。

人件費は国家公務員の給与表を用いて月例給与以外 の賞与, 厚生費, 退職金等をも考慮した年間給与額か ら 1 時間当たりの医師および看誌婦の給与係数を算出
しますこれに対し，技術度を考慮した経験年数指数 を乗じ，さらに所要時間を乗ずることにより処置料三 要素のうちの二要素, 術者と協力者の人件費の原価計 算が可能であります。

つぎは間接経費ですが，この算出が最も複雑であり ます。これは処置室なる病院の設備を単位時間使用し た場合いくら支払うべきか原価計算することで，こ れは所謂ホスピタル・フイーに該当します。この原価 計算のためには先づ開設の費用を算出します。すなわ ち, 土地を購入して処置室を建設し，また処置を行う に必要な医療機器も配備しなければなりません。また 建物や設備, 医療機器の原価償却費, 医療機器の修理 費, 建物維持管理費, 公課を算出し, それらの合計か ら単位時間当たりの間接経費を割り出します。そして これらはすべて借入金で賄うこととしていますので, その金利の計算も必要であります，以上から単位時間 当たりの間接経費が算出されてまいります。

このようにして算出された三要素, すなわち術者人 件費, 直接協力者人件費及び処置間接経費を合算して 得られた基礎報酬に，さらに付加報酬を加えることに より診療報酬として処置料が算出されるのでありま す.

この付加報酬には人件費調整分および技術料相当 分, 保険料, 事務費, 経常利益等が含まれ, 多くは無 形のものであり，原価計算により数字的に表現するこ とが極めて困難であります。手術試案では基䃈報酬に 最終的に $30 \%$ を加算することでこの問題を解決してお り，処置においてもこれを踏襲しております。

以上が外保連方式による診療報酬算定の理論と実際 でありますが, 実に詳細, 複雑で多方面にわたる検討 を必要とすることから，その道程は決して容易ではあ りません．そのことは手術試案の初版が出版されるの に14年の歳月を必要としたことからも伺えます. 現行 点数表を単に外保連用語に変えるのみではまさに本末 転倒であり，さらに詳細な検討を続け先人のご努力に 恥じないものを出版する積もりであります。

一方，現行点数表について見ますと，まさに「もの」 至上主義であります。薬は薬価基準で，また治療材料 は購入価格もしくは厚生大臣が定めた価格で評価され ていますが，すべて自由経阂の掟に基づいています。 しかも薬価は世界の $2 \sim 3$ 倍, 材料は $4 \sim 5$ 倍は高い といわれています。これに引き替え処置技術料の評価 は只今の外保連方式で算出された価格の $1 / 5$ から $1 / 10$ に過ぎません，毎回の点数改正で技術重視が嵒われま 
すが，なお低く抑えられたままであり，まさに統制経 済であります．そしてまた，その点数設定の根拠も全 く暖味であります。

技術料の抜本改正として平成 4 年の点数改正の際に 手術料が平均1.5倍引き上げられたことがありました。 これが唯一，実質的な技術料の見直しでありましたが， 今後ともぜひ技術料の適正化に向けて, せめて外保連

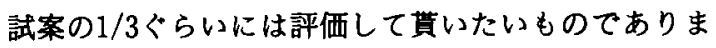

す.

以上「処置に対する診療報酬外保連試案について」 の報告を終わります，最後になりましたが，本口演を 終わるに当たり，このような機会をお与え頂きました 曾和会長, 司会の労を㧍とり頂きました出月, 日下部 両先生,また会場の皆様に厚く御礼申し上げます。ご 清聴有り難うございました。

\section{III. 検查に対する診療報酬外保連試案について}

\section{外保連検查小委員会委員長 比企 能樹}

はじめに

我が国の社会保障制度の中で, 最も大きな社会問題 となっているものに医療経済，つまり医療費の問題が ある.

医療費が国家予算の中で，かなりの部分を占めると いうことから，政府としては，医療費の抑制の政策を 開始した.このような社会的背景にあって, 私共が今, 考えなければならないことは，医療費が果たして，今 までの状況で適正, 妥当なものであったかどうか, と いうことである.これは二つの視野で考える必要があ る.その一つは，果たして，わが国の医療費が，ト一 タルとして考えたとき, 欧米と比較して, 過剩なのか どうかということ．更にもう一つの視点では，果たし て, 現在の医療費の配分方法がバランスよく行われて いるかという点である，前者において，私は，医療， 特に, 国民の健康を維持し, 疾病から離脱させるため には，かなりの経費がかかることを理解する必要があ る.この費用の捻出方法については，末だ工夫する余 地があると考えるが，ともかく，欧米に比べて，本当 に我が国が，とび技けて，総医療費が高いともいえな いのではなかろうか. 少なくとも，医療を実施する現 場, つまり，医師に対する報酬が，欧米に比して，低 いことは事実である。公的保険制度のみならず，私的 な保険を併用したやり方で，もう少し，医療現場の窮 状を改善すべきときがきていると考える.

さて, 第二の問題点は, 今回の学会のパネルディス カッションのテーマと深く関係のある点である. 即ち 現在の医療費の使われ方である。私共, 外科系社会保 険委員会連合（以下外保連という）は, 適正な医療費 とは何かについて外保連結成以来，真剣に取り組んで
きた.今回その経緯をもとに，検査小委員長としての 所見をのべたい.

なお，外保連で扱う検查とは，まず，生体検査を中 心に検討をはじめることにした，検体検査の問題も数 多く存在するので, これらについては, 現時点では, 内科領域のものが多いことから, 先づ, 内保連にて検 討をすすめていただくこととした。

\section{外保連の成り立ち}

昭和 42 年 7 月 26 日，外保連が正式に結成され，第一 回会合が開催された。これに先立つこと 2 年程前の昭 和 40 年 4 月頃から, 外科系臨床家の生命でる「手術 の報酬」に，手術の技術の評価が組み込まれていない ことなどを問題提起され, 日本外科学会, 日本麻酔学 会ちよび日本整形外科学会のメンバーが屡々集まって 会合し，本問題を協議してきた。

この問題の解決は決して容易なものではないことは わかっていても, 地味地な努力を重ねた結果, 他の外 科系学会へ呼加たところ, 日本眼科学会, 日本必存 器科学会, 日本耳鼻科学会, 日本口腔科学会, 日本産 婦人科学会が加わって, 上記外保連の結成と第一回会 合が開催された。これより数年後には，日本形成外科 学会がこれに加わり参加学会は 9 分科会となった.

当初から, 外保連の活動は, 手術小委員会, 処置小 委員会, 特殊検査小委員会の 3 委員会を設置して討議 し，昭和48年 1 月に中間報告をした. その時の検查委 員会の作業は, 生体検査の行為別分類を行ったところ までで,その後は，もっぱら，手術小委員会の活動に 集中した経緯がある。昭和 57 年 2 月には，島田信勝会 長のもとで，手術報酬に関する外保連試案の第 1 版を 出すことになった"!. 爾来15年, 外保連も三島好雄会長 
により，原点に立ち戻り，処置委員会，検査委員会が 再出発され ${ }^{2}$ ，試案作成の作業が開始された。

検查報酬に関する外保連試案の基本的性格

㭘査報酬の算定に関する基本的性格は，特に日進月 歩のはげしい領域でることを基本的に考慮して，医 学・医術に即応した学術的根拠に基づいて，一貫性の ある方式により検査料を算出することにある31. 従っ て, 検査科を算定する際に, 重要な基礎的要素として 次の 4 つのポイントを設定した（表 1 ）.

(1) 検查施行のための技術度区分

検查の技術には二つの技術がある，その一つが，検 査を行うための技術である，検査には，多くの種類が あるが, 各々に，その難易度が異なるのは当然である。 誰でもできる検査から，特別な技術と経験をもたなけ ればできない検査等, 様々な程度のものが存在し，そ の各々について, 一貫性のある方式で算出するための 難易度の設定をする必要がある。

(2) 検査診断のための技術度区分

上記の各々の検査について,検査施行中の所見及び, 検査終了後のデータ一解析等の判断能力, 即ち診断技

\section{表 1 ।，検查料算定に関する基礎的要素}

(1) 検查施行のための技術度区分（経験年数を考虑する） 自らの主体的判断で検㚗を施行できる基準

A群：研修医でできるもの

$\mathrm{B}$ 群：病棟医(シニアレジデント)レベルで行うもの

C 群：訊定医レベルでできるもの(卒業10年程度)

$\mathrm{D}$ 群：とくにトレーニングを受けた専門医でなければ できないもの

$\mathrm{E}$ 群：さらに特殊検㚗に熟澾した専門医または指䓕医 によるもの

（2）検査診断のための技術度区分（経験年数を考虑する） 自らの主体的判断で検查を施行できる基準

a 群：研修医でできるも

$\mathrm{b}$ 群：病楝医(シニアレジデント)レベルで行うもの

$\mathrm{c}$ 群：認定医レベルでできるもの(卒業10年程度)

$\mathrm{d}$ 群：とくにトレーニングを受けた専門医でなければ でないもの

e 群：さらに特殊検査に熟達した専門医または指導医 によるもの

（3）検査直接協力者数

娭者以外の人手として検查に直接協力する医師と看讙婦, 技師等の人数

(4) 検查所要時間

直接検査施行するため, 検查前, 検査中, 検査後に必要と する時間の総計とする

ただし，長時間のモニター等の検査は別に定める基準に従 う
術に対する評価を加味することが大切である。とかく， 忘れられがちな評価のポイントであり，今回は，これ を考虑することにした。

上記 (1)，(2)の各技術度の区分については, 当初か ら種々の区分が検討されたが, 最終的には，(1)の技術 度としては，A 群〜 E 群の 5 区分として，(2)の技術度 としては, a 群〜e 群の 5 区分とした. 即ちいずれも自 らの主体的判断て (1) 検查を施行し, 或いは(2)検査の 診断をする基準を，経験年数を加味して A〜E を綜合 的に13段階に区分した.つまり，(1)検査施行難易度と して, A : 研修医 1 年生或いは看蓄婦・技師でできるも の. B：研修医 2 年程度でできるもの. C：病棟医また は認定医レベルでできるもの，D：とくにトレーニン グを受けた専門医でなければできないもの，E：特群 の意味で，特に専門的な技術を要するもの（およそ13 年以上)となり，(2) 検査の診断難易度としては, $\mathrm{a}$ 群, $\mathrm{b}$ 群, c 群, d 群, e 群の基準は, 上記 (1) の基準も全 く同じものとした。

(3) 検査直接協力者数

検查は 1 人でできるものから，手術と同じように， 助手をつとめる医師看證婦, 或いは技術員 (技師), そ して，外迴りをつとめる要員をも併せ，一つの検査に 直接擭わる協力者数を算定する. 最小限, 検査を施行 するためには，医師一人は必要であるとの考えに立っ ている(看護婦或いは技師が行う検査であっても，そ のオーダーは医師が出すこと，更に，検查に関する偶 発症等の責任は，医療法上，医師がもつことになって いるからである)。

\section{(4) 検查所要時間}

検査を行うにあたって要した時間である。この内容 の分析を行ってみると，(1)検査のための前処置に要す る時間, (2)検查を害際に行っている時間, (3)検査後り カバーに要する時間ということになる. 以上の総和で 考えるのが本来と思うが，実際問題として，(2)以外の 時間の算定には，基準作りをしても，まちまちで中々 むつかしい. 従って, (1)，(2)，(3)共に，医師の監視下 に，実際に必要とする時間丈にしほっって考えることに して，例えば長時間モニターのような検査は，2 時間 までを限度として，あとは一定の比率で加算する方式 を考えた。

\section{生体検查行為別分類}

生体検査とは, 患者が, 検査室乃至はベットサイド に居るところて，検査が行われる種類のものを指す。 つまり，患者から検体を採取したものについて検查を 
行う，所謂検体検査とは区別した総称である.

外保連ては, 昭和 48 年以来, 生体検查を行為別に分 類する方式を採用した. 外保連でも, 手術小委員会に おける手術試案の作成では手術術式をコード番号化す るに当たり, 䁍器組織区分により, 解剖学的な分類毎 に各々の手術項目を分類している.

今回, 検查小委員会としては，先つ，行為別分類を 採用し, 同時に各検査項目を, 蔵器組織区分 (解剖学 的区分）に従っても分類して，その双方からの検討を 行った。

外保連, 検査委員会方式の元来の分類である行為別 分類を, われわれは今日, 時代の変遷機器の進歩, 検 查技術の発展を考慮してその変法として採用, 委員会 の第一の作業は検查項目の検討であった. 先づ当委員 会として, 各学会からの代表委員により, 各自の領域 において行われている生体俟査のすべてを列挙してい ただき，提出願った．この内容は，勿論現行の保険点 数として集載されていないものをも含めてすへてを検 討の上にのせることにして行われた. 各学会て重複し た検查項目は相互に確認しつつ，以降の作業をすすめ ていった. その結果, 検查行為別分類として, 次の 6 項目に区分した（表 2 ）。

1) 機能倹查

この項目に分類される生体検査が最も多く,251件に の浔った。その主なものとして呼吸機能検查, 循㻴機 能検査, 神経 - 筇機能検查, 消化器関係機能検查等が あるが，その他にも多くの機能検查が含まれる.

2) 内視鏡検查

この領域の検査は, 各科領域て最も著しい進步発展 を遂げた分野の一つであり，現在も日進月歩を続けて (るい). 現時点では，61件の検査が挙げられ，各科共 通の検討課題となった。

3）超音波検查

今回，行為別分類にとり入れられた項目であり，こ の検查も，各科でそれぞれの分野に導入されている. 用いる超音波の種類としても19件にわたり，これを各

表 2 外保連検査小委員会中間まとめ

<行為別分類 $>$
1) 機能検查
2) 内視鏡蚞查
3）超音波娭査
4）レントダン(造影, CT, MRI)
5) $\mathrm{RI}$
6) 診断穿刺(検查材料採取手技)

科がそれぞれの目的に従って用いている。

4）レントゲン（単純撮影・造影等）

レントゲンもその機種の進歩のめざましい分野であ る. 今回，すへての領域にわたり，広く項目を列挙し， まとめてみると，140件の検查が挙がった。

\section{5）RI（核医学を用いた生体検査）}

RIによる検査も, へモタイイナミックな機能をみる検 查として, 盛んに利用されており，41件の検查の種類 が挙がったが,これを各学会毎に, 各々の目的で使用 している.

6）検查材料採取のための生体検查

生体検査を行って，検体を採取するためには，一つ の技術を要する.やみくもに採取するのではなく，ど こから採るかの判断つまり，検査施行中の診断技術が 大きく影響を及涩すことになる，更には，採取による 偶発症を如何に防止するかといった，採取のための技 術も, 要求される. 従って, われわれは, 外保連とし て, 生体検查にこのような行為別分類の項目を独立さ せ設定した.

\section{実際の検査報酬の算定について}

以上のへた，検査報酬の算定のための基本的考え方 にのっとって, 基本的要素を加味した検査基礎報酬を 先づ算する.つまり，(1)検查人件費，(2)協力者人件費， (3)検查間接経費である.これらは, 具体的に数値計算 を各算出根拠に基づいて算出可能な項目部分である. しかし，これ以外に実際には経費がかかっているにも 拘らず，各々に分割して算出困難なものがある ${ }^{677}$. こ れらの部分は，本来間接経費に含まれるべきだが，更 に，検查付加報酬としてもまとめることにした(表 3 ). これは，手術試案の方式に準じたものである．具体的 には，基礎報酬の凡そ30\%程度を基本部分につけ加え ることになるものと考えている。

\section{おわりに}

検査小委員会の仕事として，今迄になかった，外保

\section{表 3 II，新療報酬算定に関する構成要素}

（1）検查基礎報酬

(1) 検者人件費

(2) 協力者人件費

(3) 検查間接経票

（2）検査付加報酬

(1) 人件費調整分

(2) 技術料相当分

(3) 経常利益

(4) その他 
連試案作成に向けて，参加学会各委員のたりまぬ御協 力を得て, 現在までに, 検查件数として587件(今後更 に整理・統合・追加も考えられる）を分類した。これ らの各検查一つ一つについて, 各委員で検査施行難易 度, 検査の診断難易度, 検査協力人員, 検査所要時間 を逐条審議した結果，一応のコンセンサスを得ること ができた。 そこで, 次の作業として, 各学会間で, 或 いは各検査間でのアンバランスがないかどうかの検討 を行った。

現在は，検査報酬の実際の算出作業に入った．各職 種別の人件費を平成 7 年の国家公務員俸給表より算出 し，経験年数による一覧の作成に入った．また，間接 経費としての医療機器, 検查室建物に関する費用他に ついても各学会から出された検查項目別の検討に入っ た.

総じて, 生体検査の診療報酬算出に際して, 他の手 術, 処置部門と最も異なる点は, 検査器機の減価償却 をどの様にみるかということである．放射線検査器機 等, 莫大な費用を要するものに対して, どの様に考え てゆくかという点であり,この点が, 今後, 解決して ゆかなければならない大きな問題であろう(表 4). 但 し, 今回のまとめで, 従来の検査報酬が如何に, 非理 論的に決められていたかがよく理解できた．初めてま とめようとする外保連検査試案の作業を行ってみて, 大変勉強になったと同時に今後大いに期待していただ きたい分野であることを申し述べたい.
表 4 外保連生体検査中間まとめ

\begin{tabular}{|c|c|c|c|c|c|c|}
\hline \multirow{2}{*}{ 検査項目 } & \multicolumn{2}{|c|}{ 難易度 } & \multicolumn{3}{|c|}{ 所要人数 } & \multirow{2}{*}{ 所要時間 } \\
\hline & 検查 & 診断 & 医師 & 看謓婦 & 技師 & \\
\hline 心電図 & A & $b$ & 0 & 0 & 1 & 30 \\
\hline 心拍出量 & B & b & 0 & 1 & 0 & 30 \\
\hline 心臓力テ & $\mathrm{C}$ & d & 1 & 2 & 2 & 120 \\
\hline 脳誘発電位 & D & d & 1 & 1 & 1 & 110 \\
\hline ERCP & D & d & 1 & 1 & 1 & 90 \\
\hline 脺胆管内超音波 & D & d & 1 & 1 & 1 & 90 \\
\hline 後頭下穿刺造影 & D & d & 1 & 1 & 1 & 120 \\
\hline 心冠動脈造影 & D & d & 1 & 2 & 1 & 90 \\
\hline 脺管鏡下塍生検 & $\mathrm{D}$ & $\mathrm{d}$ & 1 & 1 & 1 & 150 \\
\hline
\end{tabular}

\section{文献}

1) 外科系学会社会保険連合 (島田信勝会長)：手術報 酬に関する外保連試案 (第 1 版)，1982，外保連，東京

2）外科系学会社会保険連合 (三島好雄会長)：手術報 酬に関する外保連試案 (第 4 版)，1997, 外保連, 東京

3）比企能樹, 医療経济と外科, 外科診療 38 ：1397一 1404, 1996

4）比企能樹：内視鏡下手術の経済学，医のあゆみ 179:548-552, 1996

5) 熊井浩一郎：スコープと周辺機器の AtoZ, 消内視

鏡 $9: 1444 \sim 1662,1997$

6）比企能樹：医療材料, 用具と保険請求, 外科診療, $38: 571-576,1996$

7）石原 昭, 花井 正, 比企能樹, 渡辺 敏：繁用治 療材料と保険請求. $\mathrm{p} 42-65,1987$

\section{IV. 司会者のことば}

司会 日本臨床外科医学会副会長 出月 康夫

"日本臨床外科医学会副会長 日下部輝夫

厚生省及び政府与党は, 国の財政状況が逼迫し ている現状を直視していかに医療費を削隇する か，そのためにはどのように医療制度を改革して いくか各種審議会などを開き，模索している.

われわれ外科医にとって診療報酬適正化に向け て最も関心の深いものの一つに現在の診療報酬体 系が適切であるか否か, また支払い方式として出 来高払いが良いのか, また現在厚生省が検討して いる定額支払い方式がよいかという問題がある。

外科医は，3K といわれる職場で長時間汗を流 し, 神経をすり減らして治療にあたり,手術や術後
管理には徹夜を辞さない医療集団である.

当然，外科診療報酬では外科医の技術を適正に 評価し，報酬体系の中では「技術」と「モノ」との 分離が必要であると考えられる。米国やドイッの 医療制度のように「ドクターフィー」と「ホスピタ ルフィー」の分離が必要であると考えられるので ある.

以上のような状況を踏まえて外保連（外科系学 会社会保険連合）では外科系学会が相互に連絡を 密にし, 各科の整合性を保ちつつ, 明確な根拠を示 して, 合理的な医療保険報酬体系の実現を促進す 
る目的で 3 年前から維密な作業を進めている. 今回本学会では, 特別パネルディスカッション として「外科診療報酬の適正化」を取り上げ，外保 連の 3 つの作業委員会の委員長 (手術: 勝俣, 処 置：中村, 検查：比企)を迎えて, 各分野の取り組 み方について解説をしていただいた。

さらに,コメンテーターとして, 厚生省保険局医 療課・西山企画官, 九州大学医学部医療システム 学・信友教授, 日本医師会・系氏副会長の御三方の 出席発言をお願いした。

西山企画官は，現在の保険診療点数算定の基礎 はどのようなものに基づくのか, 社会保険 30 年の 歴史を振り返ってみても全く不明であり医療費の 配分が主として検討されてきたようだとの見解を 示した。そのような観点から, 現在, 外保連が行っ ている作業は貴重なものであるとしながらも，算 定基礎項目の詳細については再検討の余地がある のではないかと指摘された。

信友教授は，今までの保険点数の配分は多分に つぎはぎだらけであり，学問的根拠のないパッチ ワークで片付けられ，政策誘導，経済主荨型政策の ための点数設定，また，ぬけがけと思われる理不尽 な点数の不均衡が目立つことを指摘され，今後は 外保連のごとききっちりとした理論的根拠に基つ いた算定による点数の改正が必要であると提言さ れた.

日医の系氏副会長は診療報酬点数の設定, 改訂 には厚生省，日本医師会それに中医協が関与して いるが, 今回の外保連の基礎診療報酬，付加報酬の 学問的な合理的な算定作業は,技術と物の分離, 技
術とは何か，技術評価のあり方という面からも貴 重なものであり，日本医師会としては外保連に対 して絶大なるエール (声援)とサポート（支援）を 表明された。

特に日本医師会としては，若い外科医にやる気 をなくすことがないよう努力したいと結び，外保 連の活動を高く評価された。

続いて，演者同志,フロアからの発言をいただ き, 現時点で話題にのほっっいる医療費削隇問題, DRG/PPS (疾患群別定額払い方式), 技術の算定 方法などについて，活発な討論が行われた。

最後に外保連三島会長から外保連の歴史, 過 去・現在・末来について特別発言をいたたいて，パ ネルを終了した。

さて，政府が行おうとしている医療制度改革は 現在のところ, 全く渾沌としている.その中にあっ て今回の企画は経済観念にうといといわれる医 師, 特に外科医に将来展望も含めて一層の関心を 呼び起こした。手術, 処置, 検査における診療報酬 点数の合理的な算定方式を初めて会員に示したも のである。

このような学問的なきちんとした根拠に基づく 算定方式は，これまでわが国には皆無であり,内保 連でも全く手をつけていない. 今回のパネルでも 外保連の活動は当然のことながら高く評価され, それに異論をさしはさむものはみられなかった。 欲を言えば,より架っ込んだそして堀り下げた討 論を行うためには，もし少し時間の余裕がほし かった。 